\title{
Modeling Growth of Matthiola incana in Response to Saline Wastewaters Differing in Nitrogen Level
}

\author{
Catherine M. Grieve ${ }^{1}$, James A. Poss and Peter J. Shouse \\ USDA-ARS, U.S. Salinity Laboratory, 450 West Big Springs Road, Riverside, \\ CA 92507
}

\section{Christy T. Carter \\ Department of Biology, 122 Pennebaker Hall, Tennessee Tech University, Cookeville, TN 38505}

Additional index words. floriculture, mineral ion relations, phasic growth, sand cultures, stock, water reuse

\begin{abstract}
The capture and reuse of nutrient-rich greenhouse effluents may be an environmentally sound option for floriculture production, which would conserve fresh water resources and reduce off-site pollution of surface and groundwaters. This study was initiated in 24 outdoor lysimeters to determine effects of salinity and varying concentrations of nitrogen on the growth, yield, and ion relations of stock [Matthiola incana (L.) R. Br.] cultivar Cheerful White. The experiment was a $4 \times 4$ factorial, partially replicated design with four irrigation water salinities $\left(2,5,8\right.$, and $\left.11 \mathrm{dS} \cdot \mathrm{m}^{-1}\right)$ and four nitrate concentrations $\left(2.5,3.6,5.4\right.$, and $7.1 \mathrm{mmol} \cdot \mathrm{L}^{-1} ; \mathrm{N}=35,50,75$, and $\left.100 \mathrm{ppm}\right)$. Ammonium nitrogen was included in the nutrient solutions. Stem lengths were measured three times weekly. Measurements at final harvest were stem and inflorescence lengths, stem and floret diameters, number of axillary buds and florets, and shoot and root fresh weights. Time course of stem elongation was quantified as a function of thermal time with a phasic growth model. Salinity significantly delayed initiation of the exponential growth phase, shortened its duration, and reduced the rate of plant development. The overall effect was to delay time to harvest of marketable stems. Although length of the flowering stems decreased with increasing salinity, marketable stems $(\approx 60 \mathrm{~cm})$ were produced in all treatments. Mineral ion relations in the plant tissues were influenced significantly, but independently, by both salinity and nitrogen. Leaf sodium, magnesium, and chlorine concentrations increased with increasing salinity; calcium and potassium decreased. In response to increasing external nitrogen, both potassium and chlorine decreased; sodium increased, whereas calcium and magnesium were unaffected. We conclude that in closed-loop irrigation systems, the nitrogen requirements for stock are low and that growers could minimize costs and limit offsite pollution by reducing nitrogen inputs.
\end{abstract}

As water quality and quantity become more limited in many parts of the world, creative management approaches are sought to make more efficient use of degraded, generally saline, waters. The reuse of runoff from floricultural production represents an opportunity for producers to greatly reduce fresh water consumption and to prevent surface and groundwater contamination. The concept of recycling irrigation runoff from floral and nursery operations, however, is not a recent innovation. Once the federal

Received for publication 25 Feb. 2008. Accepted for publication 3 July 2008

We thank Donald A. Layfield and John Draper for ion analysis and JoAn Fargerlund, Jack Jobes, Doug Diaz, and Kathy Kim for technical assistance. We thank Sakata Seed America, Morgan Hill, CA, for donating seed for the study.

Mention of company names or products is for the benefit of the reader and does not imply endorsement, guarantee, or preferential treatment by the USDA or its agents.

${ }^{1}$ To whom reprint requests should be addressed; e-mail Catherine.Grieve@ars.usda.gov $\mathrm{gal} / \mathrm{d})$ of runoff water. Among the benefits accruing to the floricultural industry from effluent recycling were water conservation, nutrient savings, energy conservation, protection of the environment, and a favorable public image (Skimina, 1992).

Although many floricultural crops are rated salt-sensitive, numerous economically important cut flower species do, in fact, possess some degree of salt tolerance. Success of the reuse approach, therefore, depends on identification of floral species that will produce commercially and aesthetically acceptable products when irrigated with brackish water (Skimina, 1992). Crop selection, coupled with management practices that limit salt accumulation in the root media, will provide the grower with appropriate reuse options. Cut flower crops such as Limonium, Dianthus, Gypsophila, Helianthus, Matthiola, and Chrysanthemum are successfully produced under irrigation throughout the Negev Desert of Israel using local saline well waters with electrical conductivities (ECs) ranging from 2.5 to $4.5 \cdot \mathrm{dS} \cdot \mathrm{m}^{-1}$ (Shillo et al., 2002). Likewise, the glasshouse flower crop industry in the western part of The Netherlands traditionally uses moderately saline surface waters from canals and ditches (Sonneveld and Voogt, 1983).

Although the capture and reuse of greenhouse effluents for floriculture production may be environmentally and economically attractive, this practice may alter the progress of plant development as a result of the concentration of salts dissolved in the waters Salinity-induced variations in the timing of morphological events that, in turn, affect harvest date have been documented for agronomic crops. The response is clearly speciesspecific. Salinity, for example, accelerates wheat development, resulting in early maturity (Grieve et al., 1993, 1994), whereas salinity slows down the development of rice so that the nonsalinized plants are the first to mature (Zeng et al., 2002). Little information is available, however, on the influence that the reuse of degraded waters has on phenological development of floriculture crops.

The purpose of this study was to determine the effects of saline wastewaters containing different concentrations of fertilizer nitrogen on developmental timing, ion relations, growth, and quality of a commercially important cut flower. A modeling approach based on stem length development as a function of thermal time provides future

Table 1. Composition of salinizing salts and nitrate concentrations in solutions used to irrigate Matthiola incana grown in a lysimeter system.

\begin{tabular}{|c|c|c|c|c|c|c|}
\hline $\begin{array}{l}\text { Electrical } \\
\text { conductivity }\end{array}$ & $\mathrm{Ca}^{2+}$ & $\mathrm{Mg}^{2+}$ & $\mathrm{Na}^{+}$ & $\mathrm{SO}_{4}^{2-}$ & $\mathrm{Cl}^{-}$ & $\mathrm{KNO}_{3}{ }^{-\mathrm{z}}$ \\
\hline$\frac{1 \mathrm{as} \cdot 11}{2}$ & 2.6 & 3.0 & 10.6 & 3.3 & 13.2 & $2.5^{y}, 3.6,5.4^{y}, 7.1^{y}$ \\
\hline 5 & 4.8 & 7.7 & 26.6 & 8.3 & 34.8 & $2.5,3.6,5.4^{\mathrm{y}}, 7.1$ \\
\hline 8 & 7.6 & 12.7 & 43.6 & 13.6 & 57.2 & $2.5,3.6 \mathrm{y}^{\mathrm{Y}}, 5.4,7.1$ \\
\hline 11 & 10.0 & 17.9 & 61.0 & 19.1 & 80.2 & $2.5^{\mathrm{y}}, 3.6,5.4,7.1^{\mathrm{y}}$ \\
\hline
\end{tabular}

${ }^{2}$ Four separate $\mathrm{KNO}_{3}$ concentration treatments were imposed at each salinity level.

${ }^{y}$ Duplicated $\mathrm{KNO}_{3} \times$ salinity treatments.

Water Pollution Control Acts of 1956 as (n) mosed serious implications for that company led to the construction at the Azusa site of a water recycling plant capable of processing $5.3 \times 10^{6} \mathrm{~L} \cdot \mathrm{d}^{-1}(1.4$ million

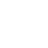

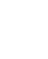


growers and researchers a potentially useful tool to estimate harvest dates for marketable flowers. The test species chosen for this study was stock (Matthiola incana) cultivar Cheerful White, a relatively salttolerant crop (Grieve et al., 2006; Lunt et al., 1954).

\section{Materials and Methods}

The experiment was conducted in a recirculating volumetric lysimeter system composed of 24 sand tanks (Poss et al., 2004). The tanks, each $82 \mathrm{~cm}$ wide $\times 202 \mathrm{~cm}$ long $\times 84$ $\mathrm{cm}$ deep, were filled with washed coarse sand having an average bulk density of $1.4 \mathrm{Mg} \cdot \mathrm{m}^{-3}$ and a volumetric water content at saturation of $0.34 \mathrm{~m}^{3} \cdot \mathrm{m}^{-3}$ and $0.1 \mathrm{~m}^{3} \cdot \mathrm{m}^{-3}$ after drainage nearly stopped. Treatment irrigation waters were pumped from 1740-L reservoirs into the lysimeters and returned by gravity through a subsurface drainage system for reuse in the next irrigation. Water lost by evapotranspiration was replenished and measured automatically to maintain constant volumes and osmotic potential in the reservoirs.

Seeds of stock (cv. Cheerful White), donated by Sakata Seed America (Morgan Hill, CA), were sown $0.5 \mathrm{~cm}$ deep in four rows ( $2 \mathrm{~m}$ long) in each of 23 tanks on $2 \mathrm{Feb}$. 2004. Rows were spaced $16 \mathrm{~cm}$ apart; withinrow spacing was $8 \mathrm{~cm}$. One sand tank was unplanted and dedicated to estimation of water evaporation from the growing substrate. Tanks were irrigated daily with a nutrient solution consisting of (in $\mathrm{mol} \cdot \mathrm{m}^{-3}$ ): $2.5 \mathrm{Ca}^{2+}, 3.0 \mathrm{Mg}^{2+}, 10.5 \mathrm{Na}^{+}, 5.0 \mathrm{~K}^{+}, 3.3$ $\mathrm{SO}_{4}{ }^{2-}, 1.3 \mathrm{Cl}^{-}, 1.0 \mathrm{NH}_{4} \mathrm{H}_{2} \mathrm{PO}_{4}, 0.10 \mathrm{Fe}$ as NaFeDTPA, $0.023 \mathrm{H}_{3} \mathrm{BO}_{3}, 0.005 \mathrm{MnSO}_{4}$, $0.0004 \mathrm{ZnSO}_{4}, 0.0002 \mathrm{CuSO}_{4}$, and 0.0001 $\mathrm{H}_{2} \mathrm{MoO}_{4}$ made up with city of Riverside municipal water. Two tanks, irrigated with this solution augmented with $\mathrm{KNO}_{3}$ $\left(2.5 \mathrm{~mol} \cdot \mathrm{m}^{-3}\right)$ served as the nonsaline control treatments $\left(\mathrm{EC}=2 \mathrm{dS} \cdot \mathrm{m}^{-1}\right)$. Nitrate treatments were imposed by adding $\mathrm{KNO}_{3}$ at sowing; salinizing salts were not added until seedling establishment. After emergence, seedlings were thinned to 25 plants per row.

The experiment was a $4 \times 4$ factorial, partially replicated design with four irrigation water salinities $\left(2,5,8\right.$, and $\left.11 \mathrm{dS} \cdot \mathrm{m}^{-1}\right)$ and four nitrate concentrations $(35,50,75$, and $\left.100 \mathrm{mg} \cdot \mathrm{L}^{-1}\right)\left(\mathrm{KNO}_{3}=2.5,3.6,5.4\right.$, and $7.1 \mathrm{mmol} \cdot \mathrm{L}^{-1}$, respectively) (Table 1 ). The experimental design included seven replicated nitrate treatments: $\mathrm{EC}=2 \mathrm{dS} \cdot \mathrm{m}^{-1}$, $\mathrm{NO}_{3}=2.5$ and $5.4 \mathrm{mmol} \cdot \mathrm{L}^{-1} ; \mathrm{EC}=5 \mathrm{dS} \cdot \mathrm{m}^{-1}$, $\mathrm{NO}_{3}=5.4 \mathrm{mmol} \cdot \mathrm{L}^{-1} ; \mathrm{EC}=8 \mathrm{dS} \cdot \mathrm{m}^{-1}, \mathrm{NO}_{3}=$ $3.6 \mathrm{mmol} \cdot \mathrm{L}^{-1}$; and $\mathrm{EC}=11 \mathrm{dS} \cdot \mathrm{m}^{-1}, \mathrm{NO}_{3}=$ 2.5 and $7.1 \mathrm{mmol} \cdot \mathrm{L}^{-1}$.

Salinizing ion concentrations were prepared to mimic the composition of typical saline tailwaters in the Coachella Valley of California and from predictions based on appropriate simulations of what the longterm composition of the water would be on further concentrations by plant-water extraction and evapotranspiration (Suarez and Simunek, 1997). Salts (Table 1) were added in two equal increments $(9$ Feb. and 23 Feb.

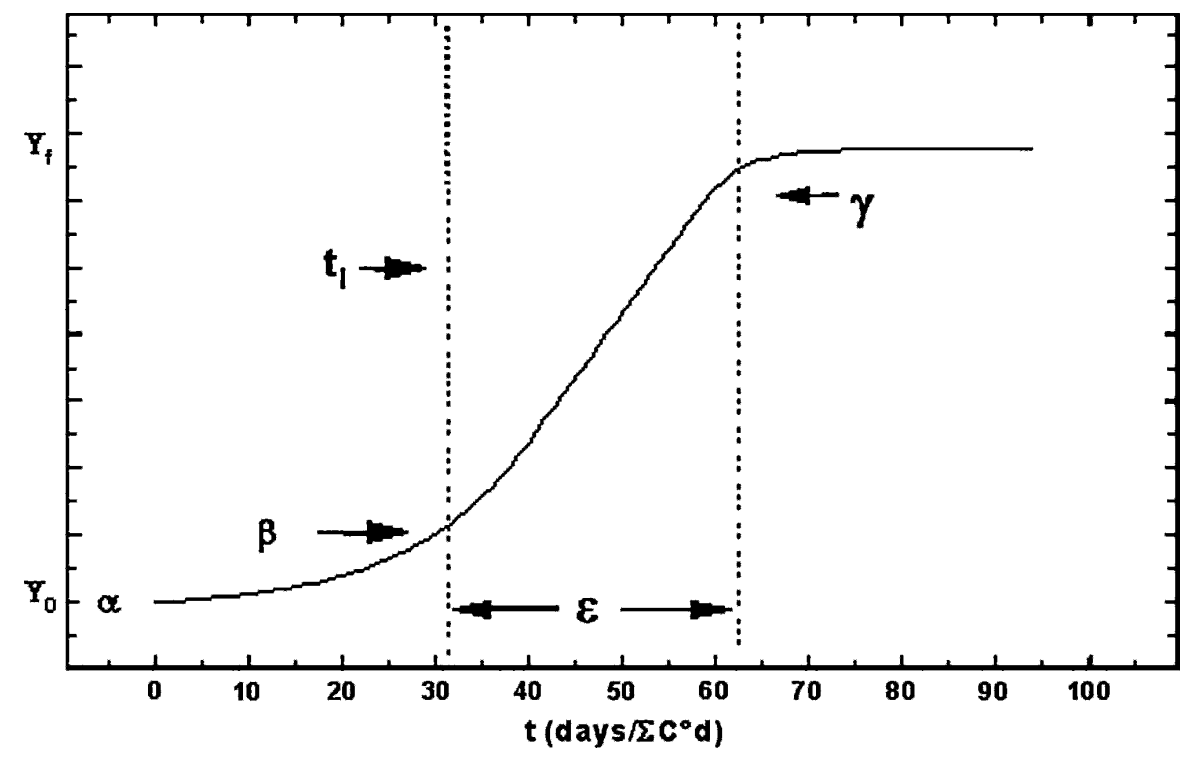

Fig. 1. Schematic of a five-parameter phasic growth model where stem length is a function of cumulative thermal time: $\alpha$ is the initial stem length 1 week after emergence, $\beta$ represents the intrinsic growth rate of the exponential phase, $t_{1}$ is the transition point between the first two phases, $\varepsilon$ is the duration of the exponential growth phase, and $\gamma$ is the intrinsic saturation rate and equals $t_{2}$, the end of the exponential growth phase (Lieth et al., 1995).

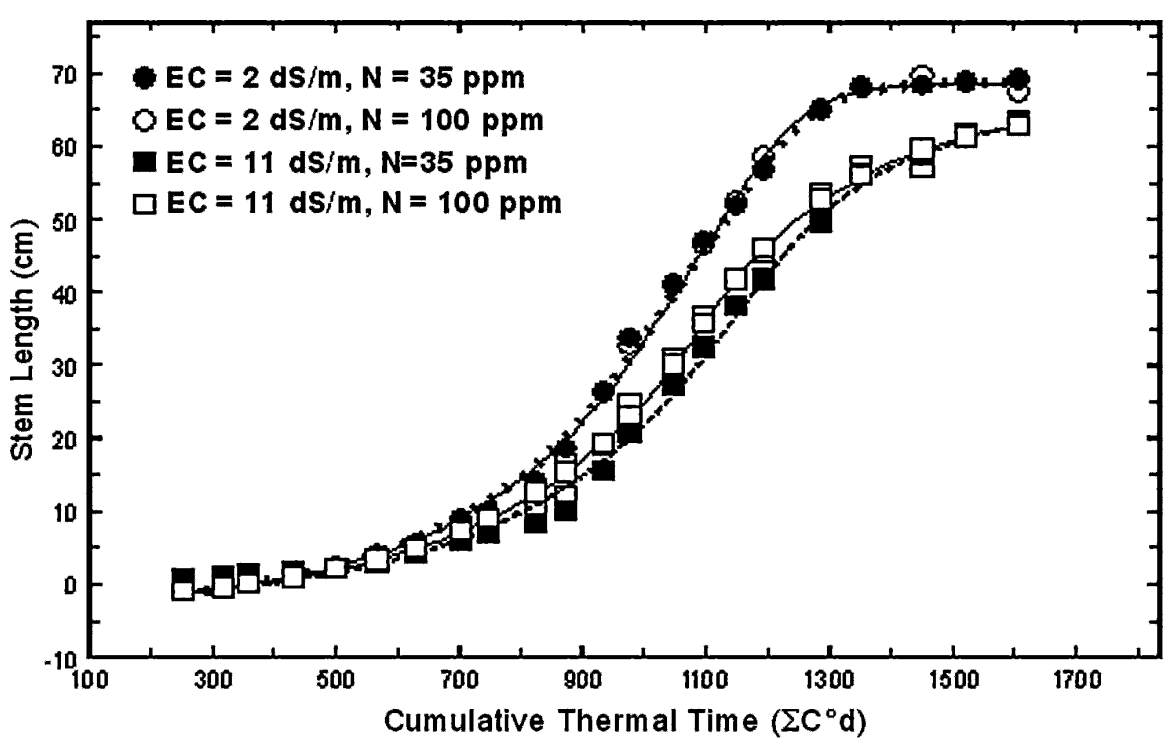

Fig. 2. Shoot growth of Matthiola incana (cv. Cheerful White) irrigated with waters at two levels of salinity ( 2 and $\left.11 \mathrm{dS} \cdot \mathrm{m}^{-1}\right)$ containing two concentrations of nitrogen $(35$ and $100 \mathrm{ppm})$. Plant height is shown as a function of thermal time $\left({ }^{\circ} \mathrm{C} \cdot \mathrm{d}^{-1}\right)$. Fitted lines were generated by the phasic growth model. Each data point is the mean of 10 measurements.

2004) to minimize osmotic shock to the seedlings. Solution $\mathrm{pH}$ was not controlled and ranged between 7.7 and 8.2 .

Nitrate concentration in the irrigation waters was measured weekly with an OI Analytical Spectrometer System Flow Solution IV (Houston, TX). Irrigation waters were analyzed by inductively coupled plasma optical emission spectrometry (ICPOES, Model Optima 3300DV; Perkin Elmer, Cambridge, MA) three times during the experiment to confirm that target ion concentrations were maintained. Chloride was determined by coulometric-amperometric titration (Cotlove, 1963).
Standard meteorological measurements were made adjacent to the experimental site with an agrometerological station. Ambient daytime air temperatures during the experiment ranged from 3.5 to $37.9{ }^{\circ} \mathrm{C}$ (mean, $\left.19.3{ }^{\circ} \mathrm{C}\right)$; nighttime temperatures ranged from 4.1 to $27.8{ }^{\circ} \mathrm{C}$ (mean, $12.9^{\circ} \mathrm{C}$ ). Relative humidity ranged from $5.5 \%$ to $97.8 \%$ with a mean of $67.0 \%$ during the night and $45.2 \%$ during the day. Hourly mean temperatures were integrated over the $24-\mathrm{h}$ period and summed to give cumulative thermal time ( $\left.\Sigma^{\circ} \mathrm{C} \cdot \mathrm{d}\right)$ (Hodges, 1991).

Beginning on $24 \mathrm{Feb}$, stem length was measured three times weekly on 10 plants 
$\mathbf{A}$

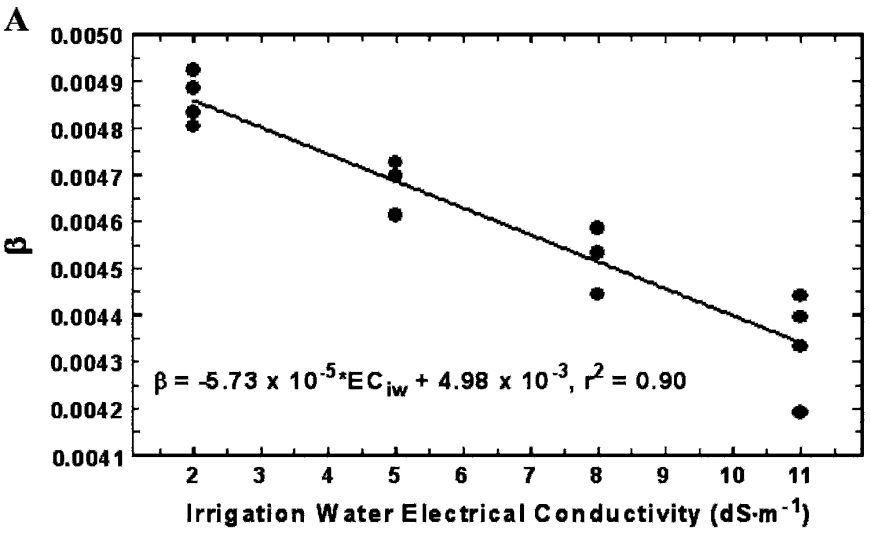

C

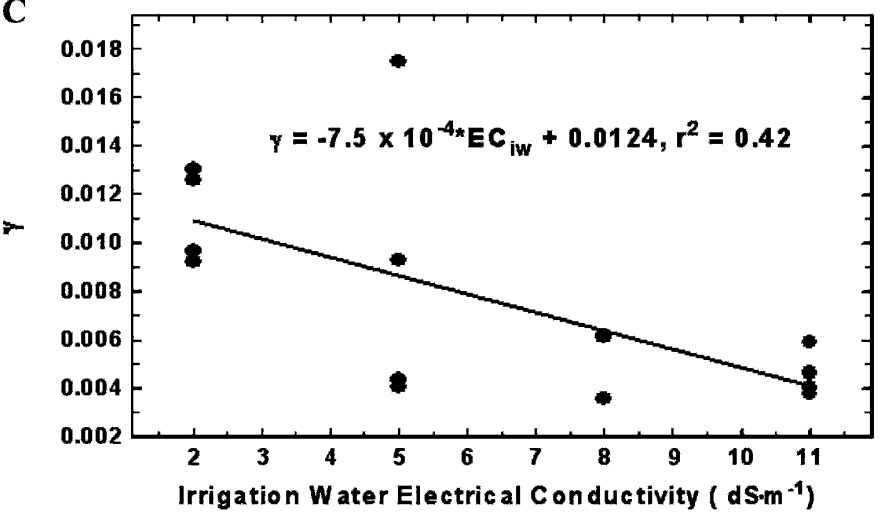

B

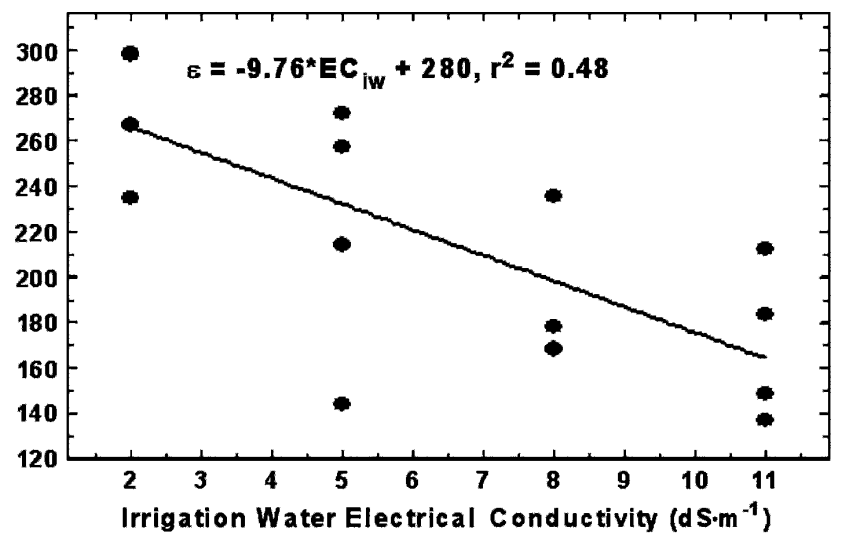

D

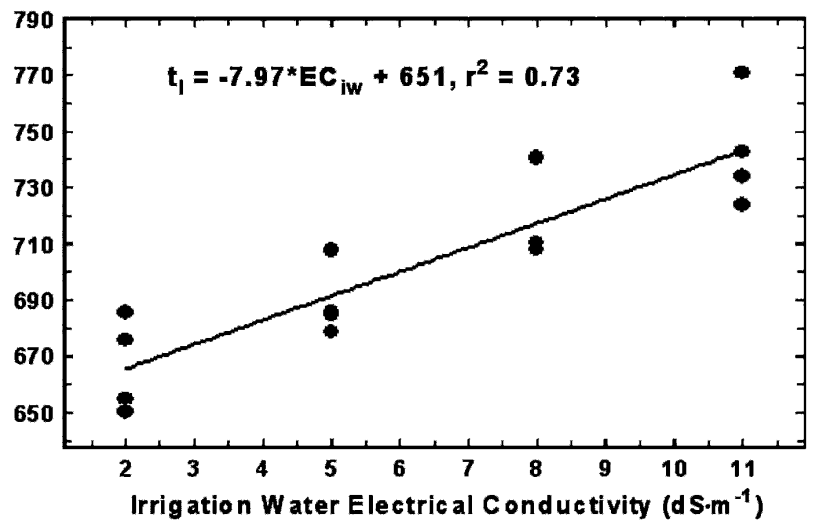

Fig. 3. Correlations between model parameters and irrigation water salinity. (A) Intrinsic growth rate of exponential phase ( $\beta$ ); (B) duration of exponential phase $(\varepsilon) ;(\mathbf{C})$ intrinsic saturation rate $(\gamma)$; (D) transition point between the first two phases $\left(t_{1}\right)$.

Table 2. Effect of irrigation water salinity on phasic growth model parameters.

\begin{tabular}{|c|c|c|c|c|c|c|}
\hline $\begin{array}{l}\text { Electrical } \\
\text { conductivity } \\
\left(\mathrm{dS} \cdot \mathrm{m}^{-1}\right)\end{array}$ & $\begin{array}{l}\text { Growth rate }(\beta) \\
\left(\mathrm{cm} \cdot \mathrm{d}^{-1}{ }^{\circ} \mathrm{C}\right)\end{array}$ & $\begin{array}{c}\text { Duration }(\varepsilon)^{\mathrm{z}} \\
\left({ }^{\circ} \mathrm{C} \cdot \mathrm{d}^{-1}\right)\end{array}$ & $\begin{array}{c}t_{1}{ }^{\mathrm{y}} \\
\left({ }^{\circ} \mathrm{C} \cdot \mathrm{d}^{-1}\right)\end{array}$ & $\begin{array}{c}t_{2}{ }^{\mathrm{x}} \\
\left({ }^{\circ} \mathrm{C} \cdot \mathrm{d}^{-1}\right)\end{array}$ & $\begin{array}{l}\text { Stem } \\
\text { length } t_{1} \\
(\mathrm{~cm})\end{array}$ & $\begin{array}{c}\text { Stem } \\
\text { length } t_{2} \\
(\mathrm{~cm})\end{array}$ \\
\hline 2 & 0.00486 & 274 & 667 & 940 & 25 & 60 \\
\hline 5 & 0.00469 & 220 & 688 & 910 & 24 & 53 \\
\hline 8 & 0.00452 & 181 & 722 & 903 & 25 & 53 \\
\hline 11 & 0.00434 & 187 & 736 & 923 & 24 & 43 \\
\hline
\end{tabular}

${ }^{\mathrm{z}}$ Duration of exponential growth phase.

${ }^{y}$ Start of exponential growth phase.

${ }^{\mathrm{x}}$ End of exponential growth phase.

that had been randomly selected and tagged in each tank. On 8 Apr., three plants were randomly selected from each tank and separated into shoots and roots. On 28 Apr., five plants were randomly selected from each tank and separated into leaves, stems, and flowers. Samples were weighed, washed in deionized water, dried in a forced-air oven at $70{ }^{\circ} \mathrm{C}$ for $72 \mathrm{~h}$, then reweighed, ground to pass a 60 -mesh screen, and stored in a glass vial for mineral ion analysis. Total S, total $\mathrm{P}$, $\mathrm{Ca}^{2+}, \mathrm{Mg}^{2+}, \mathrm{Na}^{+}$, and $\mathrm{K}^{+}$were determined on nitric-perchloric acid digests of the tissues by ICPOES. Chloride was determined on nitric-acetic acid extracts by coulometricamperometric titration. Tissue $\mathrm{N}$ analyses were performed with a LECO Carbon-Nitrogen Analyzer (Model CN2000; LECO, St. Joseph, MO).

By 28 Apr., $\approx 50 \%$ of the nonsalinized plants had reached marketable stage with $\approx 50 \%$ of the florets on the inflorescence open (Armitage, 1993; Healy, 1998). To test the phasic growth model described by Lieth et al.
(1995) (Fig. 1), however, plants were grown to full bloom. The following plant measurements were recorded at that time: stem length, diameter, and weight; inflorescence length; numbers of open florets, buds, and axillary buds; floret diameter; and root weight.

Stem length data were regressed against thermal time $\left({ }^{\circ} \mathrm{C} \cdot \mathrm{d}\right)$ with a phasic growth model as shown in Figure 1. The model was fit to the data with SAS proc NLIN, DUD method (SAS Institute, 1985). Mathematically, the model may be expressed as: emergence, $\beta$ represents the intrinsic growth rate of the exponential phase, $t_{1}$ is the transition point between the first two phases, $\varepsilon$ is the length of the linear phase, and $\gamma$ is the intrinsic saturation rate and is equal to $t_{2}$, the end of the exponential growth phase (Lieth et al., 1995).

Nitrogen depletion from the solutions was calculated as the difference between the maximum and minimum $\mathrm{NO}_{3}{ }^{-}$concentrations over the course of the experiment. Ion selectivity coefficients were calculated from the ratio of specific ions in the plant divided by the ratio of those ions in the external medium (Flowers and Yeo, 1988).

A quadratic surface response model was used for analysis of variance to test the level of significance that salinity and nitrogen treatments contributed to the fit of the experimental design response variables $(y)$ expressed as:

$$
\begin{aligned}
y= & \beta_{0}+\beta_{1} x_{1}+\beta_{2} x_{2}+\beta_{3} x_{1}{ }^{2}+\beta_{4} x_{2}{ }^{2} \\
& +\beta_{5} x_{1} x_{2}+\varepsilon
\end{aligned}
$$

$$
F(t)= \begin{cases}\alpha-1+e^{\beta^{\left(t-t_{0}\right)}} & \ldots \text { for } t_{0} \leq t \leq t \\ \alpha-1+\left(1+\beta\left(t-t_{1}\right)\right) e^{\beta\left(t_{1}-t_{0}\right)} & \ldots \text { for } t_{1}<t \leq t_{1} \\ \alpha-1+\left(1+\beta \varepsilon+\frac{\beta}{\gamma}\left(1-e^{-\gamma\left(t-t_{1}-\varepsilon\right)}\right)\right) e^{\beta\left(t_{1}-t_{0}\right)} & \ldots \text { for } t>t_{1}+\varepsilon\end{cases}
$$

where $F(t)$ is plant height as a function of time, $\alpha$ is the initial plant height 1 week after where $y$ represents the response variable, $\mathrm{x}_{1}$ and $x_{2}$ represent the actual measured average 
Table 3. Plant stem length and diameter, number of axillary buds, inflorescence dimensions, and shoot and root fresh weight of Matthiola incana as influenced by increasing salinity and nitrogen in solution ${ }^{2}$.

\begin{tabular}{|c|c|c|c|c|c|c|c|c|c|}
\hline $\begin{array}{l}\text { Electrical } \\
\text { conductivity } \\
\left(\mathrm{dS} \cdot \mathrm{m}^{-1}\right)\end{array}$ & $\begin{array}{c}\mathrm{N} \\
\left(\mathrm{mg} \cdot \mathrm{L}^{-1}\right)\end{array}$ & $\begin{array}{l}\text { Stem } \\
\text { length } \\
(\mathrm{cm})\end{array}$ & $\begin{array}{l}\text { Inflorescence } \\
\text { length } \\
(\mathrm{cm})\end{array}$ & $\begin{array}{l}\text { Stem } \\
\text { diam. } \\
(\mathrm{cm})\end{array}$ & $\begin{array}{l}\text { Axillary } \\
\text { buds } \\
\text { (no.) }\end{array}$ & $\begin{array}{c}\text { Florets } \\
\text { (no.) }\end{array}$ & $\begin{array}{l}\text { Floret } \\
\text { diam. } \\
(\mathrm{cm})\end{array}$ & $\begin{array}{l}\text { Shoot } \\
\text { fresh } \\
\text { wt. (g) }\end{array}$ & $\begin{array}{l}\text { Root } \\
\text { fresh } \\
\text { wt. (g) }\end{array}$ \\
\hline 2 & 35 & $70.4 \pm 1.7$ & $23.5 \pm 1.3$ & $0.92 \pm 0.0$ & $0.39 \pm 0.0$ & $17 \pm 0.7$ & $5.1 \pm 0.0$ & $109.1 \pm 2.9$ & $9.1 \pm 0.2$ \\
\hline 2 & 50 & 70.0 & 21.21 & 0.98 & 0.36 & 16 & 5.09 & 119.4 & 9.90 \\
\hline 2 & 100 & $67.5 \pm 1.6$ & $20.4 \pm 0.8$ & $0.97 \pm 0.01$ & $0.30 \pm 0.1$ & $15 \pm 0.5$ & $5.0 \pm 0.1$ & $116.7 \pm 5.0$ & $10.7 \pm 0.2$ \\
\hline 5 & 35 & 67.8 & 23.4 & 0.84 & 1.07 & 18 & 4.95 & 97.41 & 7.66 \\
\hline 5 & 50 & 67.3 & 23.8 & 0.85 & 0.75 & 17 & 5.98 & 107.2 & 8.04 \\
\hline 8 & 50 & $66.5 \pm 1.7$ & $23.3 \pm 1.0$ & $0.81 \pm 0.0$ & $1.3 \pm 0.1$ & $19 \pm 0.1$ & $4.7 \pm 0.2$ & $103.3 \pm 1.0$ & $7.0 \pm 0.3$ \\
\hline 8 & 75 & 65.6 & 25.5 & 0.84 & 2.02 & 18 & 4.68 & 103.3 & 6.65 \\
\hline 8 & 100 & 66.2 & 22.1 & 0.82 & 1.47 & 19 & 4.59 & 102.6 & 7.06 \\
\hline 11 & 35 & $60.1 \pm 2.7$ & $19.9 \pm 0.8$ & $0.77 \pm .03$ & $1.6 \pm 0.1$ & $16 \pm 1.3$ & $4.4 \pm 0.1$ & $86.6 \pm 5.1$ & $6.1 \pm 0.2$ \\
\hline 11 & 50 & 61.2 & 20.4 & 0.77 & 1.25 & 19 & 4.31 & 85.3 & 5.99 \\
\hline 11 & 75 & 63.0 & 21.5 & 0.75 & 1.65 & 17 & 4.44 & 87.4 & 5.88 \\
\hline
\end{tabular}

${ }^{\mathrm{z}} \mathrm{Absence}$ of some SE as a result of partial replicated design.

root zone salinity and initial irrigation water nitrogen concentrations, respectively, and $\varepsilon$ is experimental error. Coefficients of the model are calculated and the significance value or probability of obtaining at least as great an $\mathrm{F}$ ratio given that the null hypothesis is true was calculated as part of the regression analysis (RSREG procedure; SAS Institute, 1997) as was the significance of the contribution of each factor ( $\mathrm{N}$ and EC). Partial replication allowed for partitioning the total error sum of squares into lack of fit and pure error to verify that error variation in the model was not attributed to factor variables. The significance of the linear, quadratic, and crossproduct terms in the regression equation was determined.

\section{Results and Discussion}

Plant growth. The phasic growth model successfully fitted the plant height data as shown in Figure 2 where height for four treatments is plotted against thermal time. Correlations between model parameters $(\beta$, $t_{1}, \varepsilon$, and $\left.\gamma\right)$ and measured EC were significant (Fig. 3). Solution N concentration, however, had no influence on any of these parameters. The initial size parameter $(\alpha)$ was not significantly affected by either treatment. The intrinsic exponential growth rate $(\beta)$ decreased as salinity stress increased $\left(r^{2}=0.90\right.$; Fig. $3 \mathrm{~A})$. The onset $\left(t_{1}\right)$ of the exponential growth phase (Fig. 3D) for plants stressed at 11 $\mathrm{dS} \cdot \mathrm{m}^{-1}$ was delayed 70 thermal units $(\approx 4 \mathrm{~d})$ relative to the controls. Stem lengths at $t_{1}$ were not significantly affected by salinity, e.g., 25 and $24 \mathrm{~cm}$ for the plants grown at 2 and $11 \mathrm{dS} \cdot \mathrm{m}^{-1}$, respectively (Fig. 2; Table 2). The duration $(\varepsilon)$ of the exponential growth phase (Fig. 3B) also decreased from 274 to 187 thermal units as salinity increased from 2 to $11 \mathrm{dS} \cdot \mathrm{m}^{-1}$. By the end of the exponential phase, $t_{2}$ or $\left(\varepsilon+t_{1}\right)$, the nonsaline control stems had reached marketable height $(\approx 60$ $\mathrm{cm})$ with $\approx 50 \%$ of the florets in the inflorescence open. At the same time, stems from the $11 \mathrm{dS} \cdot \mathrm{m}^{-1}$ treatment were $\approx 40 \mathrm{~cm}$ long with only a few of the inflorescences showing color, and these plants required an additional $200^{\circ} \mathrm{C} \cdot \mathrm{d}$ to reach marketable height.

The delay in developmental timing found in this study contrasts markedly with the results reported by Heuer and Ravina
(2004) who observed that salinized stock plants were the first to flower and senesce. Reasons for this discrepancy may include differences in irrigation water composition and also time under treatment. Heuer and Ravina (2004) ended saline treatments and continued irrigating all plants with nonsaline water 2 months before final harvest.

For purposes of testing the growth model, plants were grown to full bloom and the effect of treatment on stock yield components at full maturity is shown in Table 3. Salinity generally reduced stem and inflorescence length, stem and floret diameter, and root and shoot fresh weights. The numbers of florets per inflorescence was unaffected by salt stress. Numbers of axillary buds increased markedly as salinity increased from 2 to $11 \mathrm{dS} \cdot \mathrm{m}^{-1}$. With the exception of root fresh weight and root/shoot ratio, the interactive effects of salinity and irrigation water $\mathrm{N}$ concentration did not significantly affect plant growth parameters (Table 4).

Yield components of stock cv. Cheerful White were considerably different from those obtained for the same cultivar and seed source grown in the greenhouse under similar

Table 4. Probability of significant effects of salinity and nitrogen treatment factors on plant harvest variables ${ }^{\mathrm{z}}$

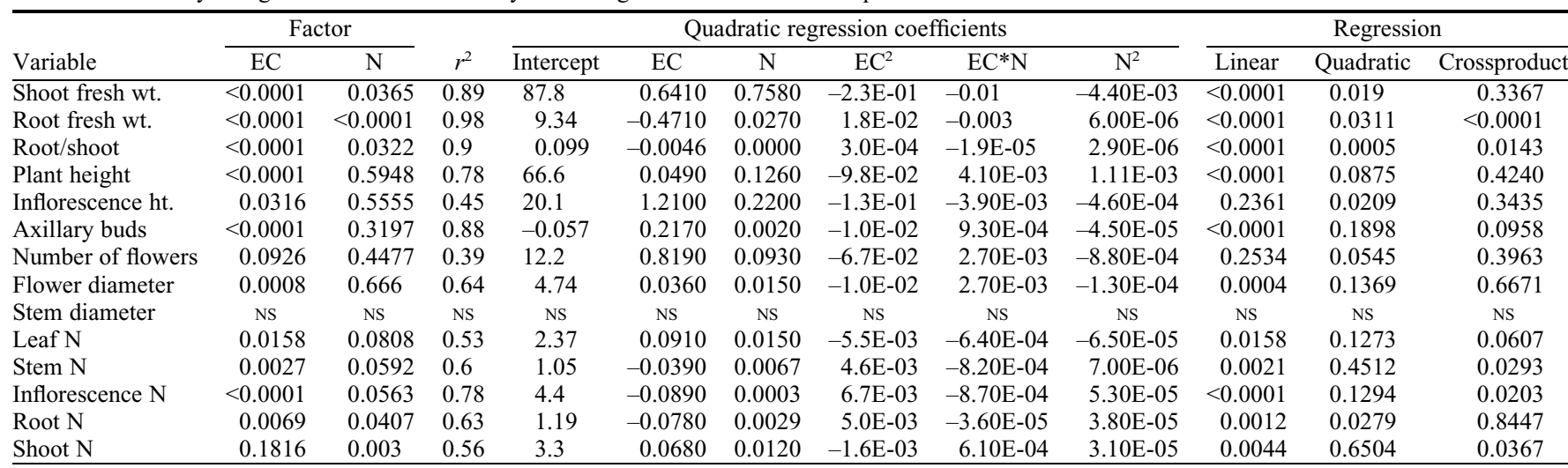

${ }^{\mathrm{z}}$ Coefficients of determination, quadratic surface response model coefficients, and regression term probabilities for linear, quadratic, and crossproduct terms in the model are given for each variable.

$\mathrm{EC}=$ electrical conductivity. 
levels of salt stress (Grieve et al., 2006). Under nonsaline conditions, stems and inflorescences were $\approx 15 \%$ shorter with fewer florets than the greenhouse plants. Lysimeter-grown plants were sturdier, however, with thicker stems (diameter, $9.5 \mathrm{~mm}$ ) compared with the greenhouse plants $(5.3 \mathrm{~mm})$. Yield, expressed as stem length of plants grown in the greenhouse, was not significantly reduced until irrigation water EC exceeded $8 \mathrm{dS} \cdot \mathrm{m}^{-1}$, whereas quality of the stems produced in the outdoor lysimeters was significantly reduced when salinity exceeded $5 \mathrm{dS} \cdot \mathrm{m}^{-1}$ (Table 3 ).

Stock is highly valued not only for its marketable flowering stems, but also as a new crop, potentially useful for dietary and industrial oils (Heuer et al., 2005). Heuer and Ravina (2004) reported that dry matter production and seed yield of stock were not significantly reduced if the EC of the irrigation waters remained less than $6 \mathrm{dS} \cdot \mathrm{m}^{-1}$. Stem length, however, was unaffected until the EC exceeded $6 \mathrm{dS} \cdot \mathrm{m}^{-1}$. Plant heights reported from the Heuer studies $(\approx 140 \mathrm{~cm})$ were considerably taller than the ones produced in either of our experimental locations.

Mineral ion relations. Plants in all treatments remained healthy during the course of the experiments and no visible symptoms of ion toxicities or nutrient deficiencies were observed. It is noteworthy that no symptoms of $\mathrm{N}$ deficiency were observed and that plant $\mathrm{N}$ status appeared to be adequate even though the lowest $\mathrm{N}$ level ( $35 \mathrm{ppm}$ ) was less than half the concentration in the modified nutrient solution recommended by Hoagland and Arnon (1950).

Quadratic surface regression analysis showed significant, but independent, effects of salinity and irrigation water $\mathrm{N}$ on plant-ion relations. Calcium, $\mathrm{Mg}^{2+}, \mathrm{Na}^{+}, \mathrm{K}^{+}$, and $\mathrm{Cl}^{-}$ were significantly affected by salinity; $\mathrm{Na}^{+}$, $\mathrm{K}^{+}$, and $\mathrm{Cl}^{-}$were significantly influenced by $\mathrm{N}$. As salinity increased from 2 to $11 \mathrm{dS} \cdot \mathrm{m}^{-1}$, leaf Ca decreased from 814 to $628 \mathrm{mmol} \cdot \mathrm{kg}^{-1}$ dry weight despite a fourfold increase of $\mathrm{Ca}^{2+}$ in the irrigation water. Leaf $\mathrm{Mg}$ increased slightly but significantly from 178 to 201 $\mathrm{mmol} \cdot \mathrm{kg}^{-1}$ dry weight as salinity increased and external $\mathrm{Mg}$ increased sixfold (data not shown).

Leaf $\mathrm{Na}$ increased from 315 to 1200 $\mathrm{mmol} \cdot \mathrm{kg}^{-1}$ as salinity and external $\mathrm{Na}$ increased (Fig. 4). Increases in $\mathrm{N}$ also increased $\mathrm{Na}^{+}$uptake. For example, as irrigation water $\mathrm{N}$ increased from 35 to $100 \mathrm{ppm}$, leaf $\mathrm{Na}$ of plants grown in the $11 \mathrm{dS} \cdot \mathrm{m}^{-1}$ treatment increased from 1200 to 1380 $\mathrm{mmol} \cdot \mathrm{kg}^{-1}$ (Fig. 4). Both salinity and increased $\mathrm{N}$ acted separately to cause significant reductions in leaf $\mathrm{K}$ (Fig. 5). The dominant stress was salinity; leaf $\mathrm{K}$ decreased from 1280 to $800 \mathrm{mmol} \cdot \mathrm{kg}^{-1}$ as salinity increased. Under control conditions, leaf $\mathrm{K}$ decreased from 1400 to 1280 $\mathrm{mmol} \cdot \mathrm{kg}^{-1}$ as $\mathrm{N}$ increased from 35 to 100 ppm (Fig. 5). The ratio of $\mathrm{K}^{+}$to $\mathrm{Na}^{+}$in leaf tissue decreased markedly from 3.6 to 0.59 as salinity increased to $11 \mathrm{dS} \cdot \mathrm{m}^{-1}$ and external $\mathrm{Na}$ increased from 10 to $61 \mathrm{mmol} \cdot \mathrm{L}^{-1}$. Ordinarily, such a low $\mathrm{K}^{+}: \mathrm{Na}^{+}$would suggest that plant $\mathrm{K}$ would be inadequate for the normal

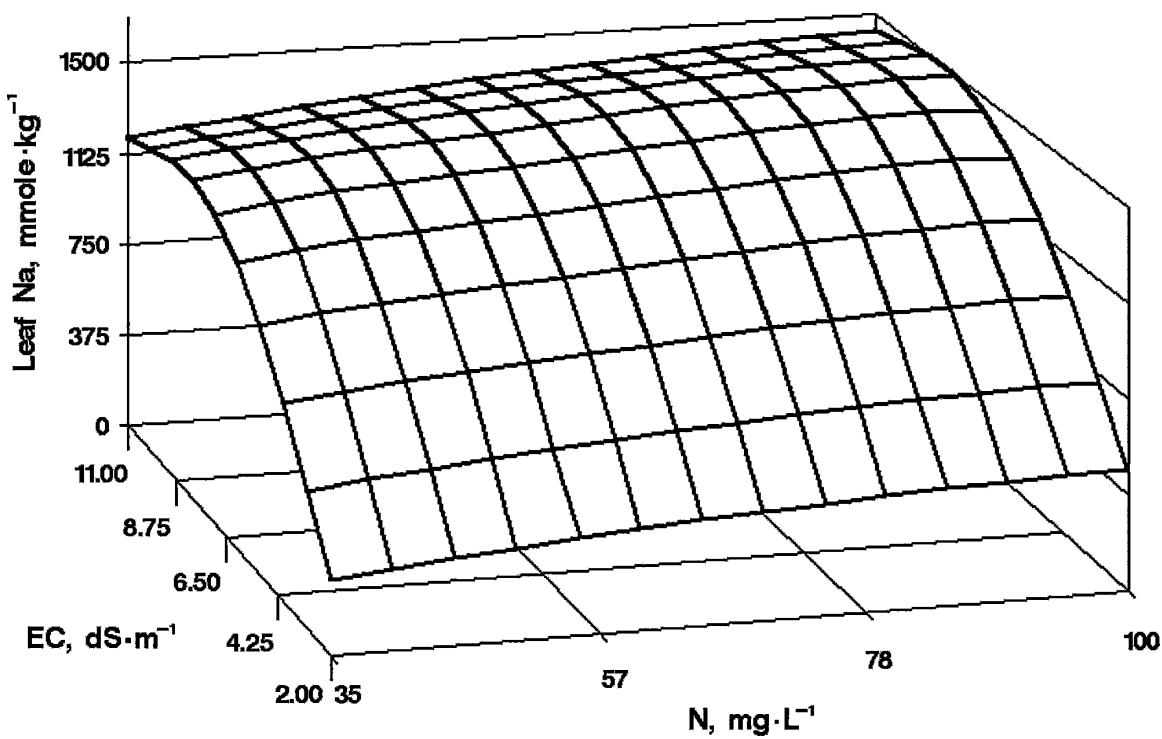

Fig. 4. Predicted surface relationship of sodium concentration in Matthiola incana leaves as a function of salinity and nitrogen in the irrigation water.

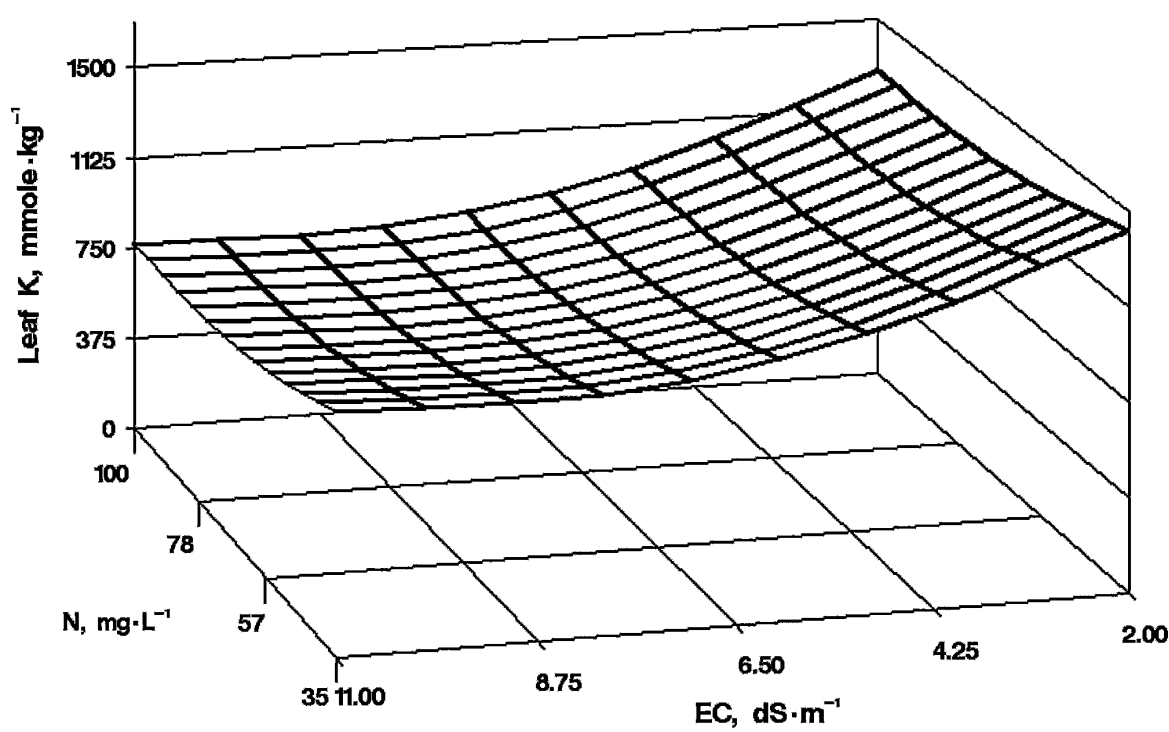

Fig. 5. Predicted surface relationship of potassium concentration in Matthiola incana leaves as a function of salinity and nitrogen in the irrigation waters.

functioning of many metabolic processes (Ashraf, 1994; Maathuis and Amtmann, 1999). However, the $\mathrm{K}$ status of stock did not appear to be impaired. The cultivar showed a strong preference of $\mathrm{K}^{+}$over $\mathrm{Na}^{+}$, and the value of the selectivity coefficient $\left(\mathrm{S}_{\mathrm{K}, \mathrm{Na}}\right)$ at the highest salinity (7.2) was only slightly lower than that in the nonsalinized leaves (7.6).

Leaf $\mathrm{Cl}$ increased significantly from a mean of 380 to 980 as salinity increased to $11 \mathrm{dS} \cdot \mathrm{m}^{-1}$. At each salinity level, however, leaf- $\mathrm{Cl}$ decreased as external $\mathrm{N}$ increased from 35 to $100 \mathrm{ppm}$ (2.5 to $7.1 \mathrm{~mm}$ ). This effect was most pronounced in the control plants in which leaf $\mathrm{Cl}$ decreased $40 \%$ (480 to $\left.290 \mathrm{mmol} \cdot \mathrm{kg}^{-1}\right)$ as N rose from 35 to $100 \mathrm{ppm}$ (2.5 to $7.1 \mathrm{~mm}$ ) (Fig. 6). Antagonism of $\mathrm{NO}_{3}{ }^{-}$ on $\mathrm{Cl}^{-}$uptake and accumulation has been observed in numerous annual horticultural species (Bar et al., 1997; Kafkafi et al., 1982; Martinez and Cerdá, 1989). Leaf damage and growth reduction resulting from $\mathrm{Cl}^{-}$toxicity in many plants is often mitigated through application of nitrate (Grattan and Grieve, 1999). Stock, however, does not appear to be prone to specific ion toxicities and increases in substrate $\mathrm{N}$ did little to improve the salt tolerance of the crop. Moreover, stock appears to be tolerant of substrate $\mathrm{Cl}$ concentrations less than $85 \mathrm{~mm}$ (Lunt et al., 1954) as was the case in this lysimeter study.

Nitrogen was differentially distributed among plant parts and lower in the roots $(0.9 \%)$ and stems $(\approx 1.1 \%)$ than in the inflorescences $(\approx 4 \%)$ and leaves $(3 \%)$. Total leaf $\mathrm{N}$ significantly increased from $2.9 \%$ to $3.3 \%$ in the nonsaline control plants as external $\mathrm{N}$ 


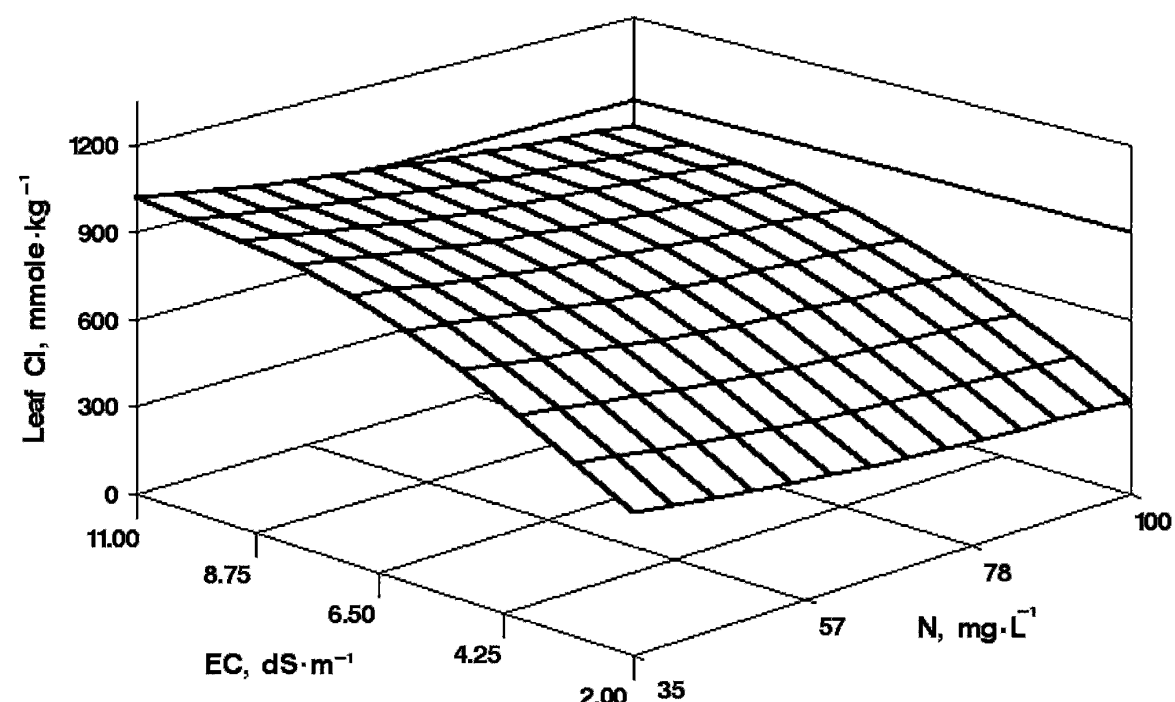

Fig. 6. Predicted surface relationship of chloride concentration in Matthiola incana leaves as a function of salinity and nitrogen in the irrigation waters.

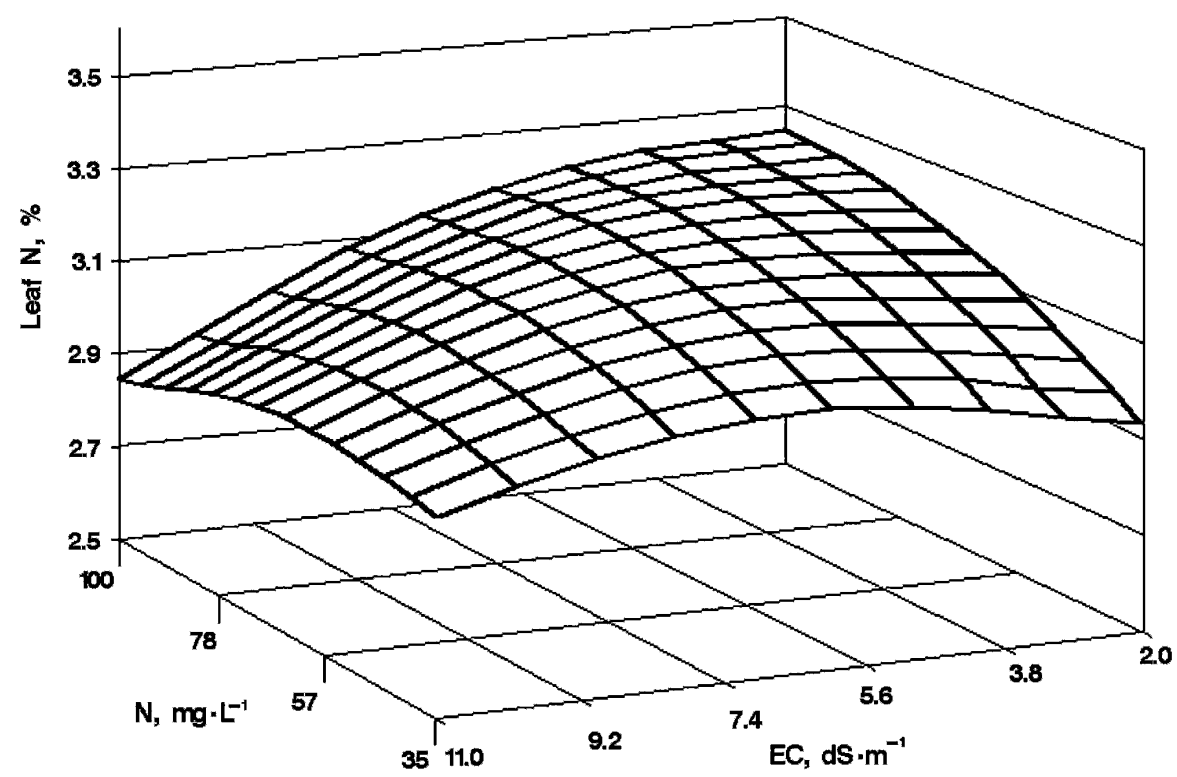

Fig. 7. Predicted surface relationship of nitrogen concentration in Matthiola incana leaves as a function of salinity and nitrogen in the irrigation waters. increased from 35 to 100 ppm (Fig. 7). Total $\mathrm{N}$ in inflorescences of nonsaline stems showed a similar response, increasing from $4.2 \%$ to $4.7 \%$. At higher salinity levels, neither leaf nor inflorescence $\mathrm{N}$ was affected by $\mathrm{N}$ concentration in the irrigation waters. Leaf $\mathrm{N}$ in young, actively growing stock leaves reportedly contain $4.5 \%$ to $5 \%$ total $\mathrm{N}$, which decreases with age (Yang et al., 1998). Lower leaf $N$ concentration $(\approx 3 \%)$ determined in the present study may have been a result of sampling and compositing fully expanded, older leaves.

\section{Conclusions}

This study demonstrates that a commercially important cut flower species is a suit- icantly, but independently, by both salinity and $\mathrm{N}$.

\section{Literature Cited}

Armitage, A.M. 1993. Specialty cut flowers. Varsity Press-Timber Press, Portland, OR.

Ashraf, M. 1994. Breeding for salinity tolerance in plants. Crit. Rev. Plant Sci. 13:17-42.

Bar, Y., A. Apelbaum, U. Kafkafi, and R. Goren. 1997. Relationship between chloride and nitrate and its effect on growth and mineral composition of avocado and citrus plants. J. Plant Nutr. 20:715-731.

Cotlove, E. 1963. Determination of true chloride content of biological fluids and tissues. II. Analysis by simple, nonisotopic methods. Anal. Chem. 35:101-105.

Flowers, T.J. and A.R. Yeo. 1988. Ion relations of salt tolerance, p. 392-416. In: Baker, D.A. and J.L. Hall (eds.). Solute transport in plant cells and tissues. John Wiley \& Sons, New York, NY.

Grattan, S.R. and C.M. Grieve. 1999. Salinitymineral nutrient relations in horticulture crops. Sci. Hort. 78:127-157.

Grieve, C.M., L.E. Francois, and E.V. Maas. 1994. Salinity affects the timing of phasic development in spring wheat. Crop Sci. 34:1544-1546.

Grieve, C.M., S.M. Lesch, E.V. Maas, and L.E. Francois. 1993. Leaf and spikelet primordia initiation in salt-stressed wheat. Crop Sci. 33: 1286-1294.

Grieve, C.M., J.A. Poss, and C. Amrhein. 2006. Response of Matthiola incana to irrigation with saline wastewaters. HortScience 41:119-123.

Healy, W. 1998. Stock as a cut flower, p. 641-645. In: Ball, V. (ed.). Ball redbook. 16th ed. Ball Publishing, Batavia, IL.

Heuer, B. and I. Ravina. 2004. Growth and development of stock (Matthiola incana) under salinity. Austr. J. Agr. Res. 55:907-910.

Heuer, B., I. Ravina, and S. Davidov. 2005. Seed yield, oil content, and fatty acid composition of stock (Mathiola incana) under saline irrigation. Aust. J. Agr. Res. 56:45-47.

Hoagland, D.R. and D.I. Arnon. 1950. The water culture method for growing plants without soil. Circular 247. Calif. Agr. Exp. Sta. University of California, Berkeley, CA.

Hodges, T. 1991. Predicting crop phenology. CRC Press, Boca Raton, FL.

Kafkafi, U., N. Valoras, and J. Letey. 1982. Chloride interaction with nitrate and phosphate. J. Plant Nutr. 5:1369-1385.

Lieth, J.H., P.R. Fisher, and R.D. Heins. 1995. A three-phase model for the analysis of sigmoid patterns of growth. HortScience 30:761.

Lunt, O.R., A.M. Kofranek, and S.A. Hart. 1954. Tolerance of six stock (Matthiola incana) varieties to saline conditions. Proc. Amer. Soc. Hort. Sci. 64:431-436.

candidate for saline water tively salt-tolerant species, produced marketable stems under irrigation with saline solutions ranging from 2 to $11 \mathrm{dS} \cdot \mathrm{m}^{-1}$ amended with substrate $\mathrm{N}$ concentrations ranging from 35 to $100 \mathrm{ppm}$. The phasic growth model satisfactorily described the time course of plant development. Salinity reduced growth rate and delayed time to harvest. Neither growth parameters nor yield components were significantly affected by increases in substrate N. This study established that, in closed-loop irrigation systems, the $\mathrm{N}$ requirements for stock are low and that growers could minimize costs and limit offsite pollution potential by reducing $\mathrm{N}$ inputs. Mineral ion relations were influenced signif-

Maathuis, F.J.M. and A. Amtmann. 1999. $\mathrm{K}^{+}$ nutrition and $\mathrm{Na}^{+}$toxicity: The basis of cellular $\mathrm{K}^{+} / \mathrm{Na}^{+}$ratios. Ann. Bot. (Lond.) 84:123-133.

Martinez, V. and A. Cerdá. 1989. Influence of N source on rate of $\mathrm{Cl}, \mathrm{N}, \mathrm{Na}$, and $\mathrm{K}$ uptake by cucumber seedlings grown in saline conditions. J. Plant Nutr. 12:971-983.

Poss, J.A., W.B. Russell, P.J. Shouse, R.S. Austin, S.R. Grattan, C.M. Grieve, J.H. Lieth, and L. Zeng. 2004. A volumetric lysimeter system (VLS): An alternative to weighing lysimeters for plant-water relations studies. Comp. Elect. Agr. 43:55-68.

SAS Institute. 1985. Proc NLIN. SAS user's guide: Statistics. Version 5. SAS Inst., Inc. Cary, NC.

SAS Institute. 1997. RSREG procedure. SAS Inst., Inc. Cary, NC. 
Shillo, R., M. Ding, D. Pasternak, and M. Zaccai. 2002. Cultivation of cut flower and bulb species with saline water. Sci. Hort. 92:41-54.

Skimina, C.A. 1980. Salt tolerance of ornamentals. Proc. of the International Propagation Society 30:113-118

Skimina, C.A. 1992. Recycling water, nutrients and waste in the nursery industry. HortScience 27:968-971.
Sonneveld, C. and W. Voogt. 1983. Studies on the salt tolerance of some flower crops grown under glass. Netherlands J. Agr. Sci. 36:63-73.

Suarez, D.L. and J. Simunek. 1997. UNSATCHEM Unsaturated water and solute transport model with equilibrium and kinetic chemistry. Soil Sci. Soc. Amer. J. 61:1633-1646.

Yang, X.Z., A. Ido, and M. Yamanouchi. 1998 Nutriphysiology of stock (Matthiola incana $r$. Br.) I. Morphological characteristics of the individual leaves developing and their ontogenic changes with respect to nitrogen and phosphorus. J. Jpn. Soc. Hort. Sci. 67:439-445 (abstr.).

Zeng, L., M.C. Shannon, and C.M. Grieve. 2002. Evaluation of salt tolerance in rice genotypes for multiple agronomic parameters. Euphytica 127:235-245. 